may look forward to its companion volume on fractures which we are promised in the preface.

A.W.L.K.

\section{ESSENTIALS OF FORENSIC MEDICINE}

By C. J. Polson, M.D., F.R.C.P. Pp. $x+56 r$. London: English Universities Press. 1955. 30s.

This is an entirely new work on forensic medicine and differs in many respects from other textbooks on the subject. Professor Polson is a doctor, barrister and a scholar, and each branch of his learning is reflected in his book. As a doctor he has written with authority on the medical aspects of crime, emphasizing those which interest him most, such as mechanical asphyxia and identification. As a barrister he has introduced a great deal more law than is usual into his text, thus increasing its value and interest to members of the legal profession. As a scholar he has written 539 pages on forensic medicine, less toxicology, without an illustration, his descriptive powers being such that illustration is almost superfluous, and has combed the world's forensic literature, not only augmenting his own personal experiences, but supplying very many valuable references to be found in no other British book on the subject. Not only do his references come from British, American and Continental textbooks and literature, but also from biographies, the Penguin series, and even the daily Press. In the latter case references would be of more value if he had referred to subsequent articles on the cases which have appeared in legal or medical publications where they are readily available.

In his preface Professor Polson says his book is primarily intended for students of law and medicine. One feels that, despite the author's clear presentation, it is too large and detailed a book for the undergraduate, but for those who practise forensic medicine Professor Polson's new book, besides being a pleasure to read, will also serve as a most valuable source of reference.

A.K.M.

\section{BROMPTON HOSPITAL REPORTS} VOL. XXIII, 1954

Pp. ix +326 , illustrated. Aldershot: Gale and Polden. 1956. I 5 s.

Twenty articles are reprinted in this new edition of the Brompton Hospital Reports. These cover a very wide range of diseases of the heart and lungs and included is Dr. Paul Wood's valuable 'Appreciation of Mitral Stenosis.' This is a clinica study of 300 patients with mitral valve disease 3 half of these were operated upon. There are four articles on chronic bronchitis. These illustrate. clinical, pathological and bacteriological features of this condition which, although the commonest? chest disease, has had extraordinarily little attention paid to it. This publication is recommended to allo interested in the management of chest diseases.

L.L.B.

\section{THE TREATMENT OF RENAL FAILURE: THERAPEUTIC PRINCIPLES IN THE MANAGEMENT OF ACUTE AND CHRONIC URAEMIA}

By John P. Merrill, M.D. Pp. $x+238$, with 3 的 illustrations. London: Grune \& Stratton Inc. I 955 . $\$ 6.75$.

Dr. John Merrill has written an excellent accounto of the therapeutic principles governing the manage- ment of acute and chronic uraemia. There is ac clear description of normal renal function and body electrolyte balance, followed by an account of the signs and symptoms of renal failure, of the courgeco of acute and chronic uraemia and of the indicationsor for treatment by extra-renal routes. His approact. that of the experienced and sensible clinician woo is also a physiologist, is admirably balanced and his style is clear and most readable. There is ano account of the work done in the author's depart-气 ment at the Peter Bent Brigham Hospital on the transplantation of the human kidney. There are $\overrightarrow{\vec{\theta}}$ 302 references and a good index.

Several controversial points, such as the significance of the E.C.G. in potassium disturbances and the use of fat in the dietary management of acute renal failure, are sensibly discussed without preju- $\frac{0}{3}$ dice. Possibly the author slightly over-emphasizes:the importance of interstitial oedema of the kidney? in uraemia. The original concept of 'uraemic lung' was based on pathological evidence, and theo absence of a distinctive radiological appearance does not rule out its existence. (There is noo reference to Doniach's paper, published in America. $)$

Estimation of P.A.H. extraction does not ruleo out the possibility of tubular back diffusion causing erroneously low values for P.A.H. clearance ins acute renal failure. But these are minor criticisms of an admirable little book. 